\title{
Hubungan Status Gravida dan Usia Ibu terhadap Kejadian Preeklampsia di RSUP Dr. M. Djamil Padang Tahun 2012-2013
}

\author{
Oktaria Denantika ${ }^{1}$, Joserizal Serudji², Gusti Revilla ${ }^{3}$
}

\section{Abstrak}

Preeklampsia merupakan penyakit dengan angka morbiditas dan mortalitas yang tinggi. Penyebab pasti terjadinya preeklampsia belum diketahui, namun terdapat faktor risiko yang mempengaruhi kejadian preeklampsia. Tujuan penelitian ini adalah untuk mengetahui hubungan status gravida dan usia ibu terhadap kejadian preeklampsia di RSUP Dr. M. Djamil Padang pada tahun 2012-2013. Penelitian ini dilaksanakan pada bulan Januari 2014 sampai Februari 2014 di bagian Rekam Medis dengan menggunakan desain cross sectional study komparatif terhadap 81 pasien preeklampsia dan 81 ibu hamil tidak preeklampsia yang bersalin di RSUP Dr. M. Djamil Padang pada tahun 2012-2013. Hasil penelitian menunjukkan proporsi primigravida yang menderita preeklampsia 1,52 kali lebih banyak daripada primigravida yang tidak preeklampsia. Proporsi ibu yang berusia dalam kategori usia risiko tinggi $(<20$ tahun dan $>35$ tahun) dan menderita preeklampsia 4,43 kali lebih banyak daripada yang tidak menderita preeklampsia. Setelah dilakukan analisis melalui uji chi square, disimpulkan bahwa terdapat hubungan yang signifikan antara status gravida dan usia ibu dengan kejadian preeklampsia $(p<0,05)$.

Kata kunci: preeklampsia, status gravida, usia ibu

\begin{abstract}
Preeklampsia is a disease with high morbidity and mortality. The exact cause of preeklampsia still unknown, but there are risk factors that affect the preeklampsia's incident. The objective of this study was to determine the correlation between gravidity and maternal age with preeklampsia's incident in RSUP Dr. M. Djamil Padang on $2012-$ 2013.The research was did in January 2014 to February 2014 at Medical Records department using cross sectional study comparative's design toward 81 preeclamptic patients and 81 pregnant women who didn't preeklampsia, which gave birth in RSUP Dr. M. Djamil Padang on 2012 - 2013. The results showed that the proportion of primigravidae who suffer from preeklampsia is 1.52 times more than primigravidae who do not. Proportion of mother who is in the age category of high risk (<20 years and > 35 years) and suffer from preeklampsia is 4.43 times more than who don't .After analyzed by chi square test, it is concluded that there are significant correlation between gravidity and maternal age with preeklampsia's incident in RSUP Dr. M. Djamil Padang on $2012-2013(p<0.05)$.
\end{abstract}

Keywords: preeklampsia, gravidity, maternal age

Affiliasi penulis : 1. Pendidikan Dokter FK UNAND (Fakultas Kedokteran Universitas Andalas Padang), 2. Bagian Kebidanan FK UNAND/RSUP Dr. M. Djamil Padang, 3. Bagian Anatomi FK UNAND

Korespondensi : Oktaria Denantika, E-mail:

oktariadenantika@gmail.com,Telp: 085375173675

\section{PENDAHULUAN}

Preeklampsia adalah penyakit dengan gejala klinis berupa hipertensi dan proteinuria yang timbul karena kehamilan akibat vasospasme dan aktivasi endotel saat usia kehamilan di atas 20 minggu. Preeklampsia terjadi pada 3,9\% dari semua wanita hamil di seluruh dunia. Angka kejadiannya di beberapa rumah sakit di Indonesia juga cenderung meningkat, yaitu $1,0 \%-1,5 \%$ pada sekitar $1970-2000 .^{1-3}$

Preeklampsia merupakan salah satu penyulit dalam kehamilan yang menyebabkan sakit berat, kecacatan jangka panjang, serta kematian pada ibu, janin dan neonatus.Kehamilan yang disertai preeklampsia tergolong kehamilan yang berisiko tinggi 
karena preeklampsia merupakan penyebab dari 30\% $40 \%$ kematian maternal dan 30\% - 50\% kematian perinatal. $^{3-5}$

Ada banyak faktor risiko yang mempengaruhi terjadinya preeklampsia, seperti primigravida, hiperplasentosis, usia ibu yang ekstrem (kurang dari 20 tahun dan lebih dari 35 tahun), riwayat keluarga pernah preeklampsia/eklampsia, penyakit ginjal, diabetes mellitus, hipertensi kronik yang sudah diderita sebelum hamil (preeklampsia superimposed) dan obesitas. $^{1,6,7}$

Preeklampsia lebih sering terjadi pada primigravida dibandingkan dengan multigravida. Dari seluruh primigravida, $7,6 \%$ didiagnosis menderita preeklampsia. Primigravida mempunyai risiko yang lebih besar untuk mengalami preeklampsia karena pada primigravida mekanisme imunologik dalam pembentukan blocking antibody terhadap antigen plasenta oleh HLA-G (human leukocyte antigen G) belum sempurna dibandingkan dengan multigravida. ${ }^{1,4}$

Wanita yang hamil pada usia ekstrem $(<20$ tahun atau > 35 tahun) memiliki risiko yang lebih tinggi untuk mengalami preeklampsia dibandingkan dengan wanita yang hamil pada usia reproduksi (20 - 35 tahun). Ibu hamil yang berusia $<20$ tahun dan $>35$ tahun cenderung mengalami preeklampsia berat dibandingkan dengan ibu hamil yang berusia 20 tahun sampai 35 tahun. ${ }^{1,8}$

Ibu hamil pada usia < 20 tahun mempunyai risiko terjadi preeklampsia 3,58 kali lebih besar dibandingkan ibu hamil yang berusia 20-35 tahun. Hal ini terjadi karena fisik dan psikis pada seorang wanita yang usianya terlalu muda belum siap dalam menghadapi kehamilan dan persalinan. ${ }^{8}$

Wanita usia > 35 tahun mempunyai risiko untuk menderita hipertensi kronik yang akan berlanjut menjadi superimposed preeclampsia ketika sedang hamil. $^{1,9}$

Angka morbiditas dan mortalitas ibu dan janin akibat preeklampsia hingga saat ini masih tinggi, dimana status gravida dan usia ibu merupakan dua dari beberapa faktor risiko yang mempengaruhi timbulnya preeklampsia. Berdasarkan studi pendahuluan, status gravida dan usia ibu merupakan faktor risko yang datanya selalu lengkap tertera pada rekam medis RSUP Dr. M. Djamil Padang. Oleh sebab itu, tujuan penelitian ini adalah menentukan hubungan antara status gravida dan usia ibu dengan kejadian preeklampsia di RSUP Dr. M. Djamil Padang tahun $2012-2013$.

\section{METODE}

Penelitian cross-sectional study komparatif ini dilakukan pada bulan Januari sampai Februari 2014 di Bagian Rekam Medis RSUP Dr. M.Djamil Padang. Populasi adalah seluruh rekam medis ibu melahirkan yang menderita preeklampsia dan yang tidak preeklampsia di Bagian Obstetri dan Ginekologi RSUP Dr. M. Djamil Padang tahun 2012 - 2013. Jumlah sampel pada penelitian ini sebanyak 162 orang, dimana 81 data pasien preeklampsia dan 81 data pasien tidak preeklampsia. Pasien yang telah memenuhi kriteria inklusi dan eksklusi diminta mengisi kuesioner. Data yang diperoleh diolah dan dianalisis menggunakan uji chi square. Variabel independennya adalah status gravida dan usia ibu, sementara variabel dependen adalah nilai preeklampsia.

\section{HASIL}

Penelitian ini dilakukan terhadap pasien preeklampsia dan tidak preeklampsia yang melahirkan di RSUP Dr. M. Djamil Padang pada tahun 2012 2013. Jumlah penderita preeklampsia yang dirawat dan tercatat di bagian rekam medis RSUP Dr. M. Djamil Padang pada tahun 2012 adalah 193 orang dari 1.682 persalinan dan pada tahun 2013 ada 206 orang dari 1.714 persalinan. Setelah dilakukan pemilihan subyek penelitian berdasarkan kriteria yang telah ditentukan, didapatkan 162 data pasien yang memenuhi kriteria untuk dijadikan sampel pada penelitian ini.Jumlah tersebut telah memenuhi besar sampel minimal dari rumus yang telah ditentukan.

\section{Karakteristik Pasien}

Tabel 1. Karakteristik Data Pasien Preeklampsia

\begin{tabular}{ccccc}
\hline \multirow{2}{*}{$\begin{array}{c}\text { Klasifikasi Usia } \\
\text { Ibu }\end{array}$} & \multicolumn{2}{c}{ Preeklampsia } & Total & $\%$ \\
\cline { 2 - 3 } & $\begin{array}{c}\text { Primi- } \\
\text { gravida }\end{array}$ & $\begin{array}{c}\text { Multig- } \\
\text { ravida }\end{array}$ & & \\
\hline$<20$ tahun & 4 & 0 & 4 & 4,9 \\
\hline $20-35$ tahun & 30 & 20 & 50 & 61,7 \\
\hline$>35$ tahun & 4 & 23 & 27 & 33,3 \\
\hline Total & 38 & 43 & 81 & \\
\hline$\%$ & 46,9 & 53,1 & & 100
\end{tabular}


Dari tabel 1 dapat dilihat bahwa multigravida $(53,1 \%)$ lebih banyak menderita preeklampsia dibandingkan dengan primigravida (46,9\%). Pasien preeklampsia yang berusia 20 - 35 tahun merupakan pasien yang paling banyak, yaitu $61,7 \%$. Dari 38 orang primigravida, 30 orang diantaranya berusia $20-35$ tahun. Sedangkan pada multigravida, yang berusia 20 - 35 tahun dan > 35 tahun hampir sama banyak serta tidak ada yang berusia $<20$ tahun.

Tabel 2. Karakteristik Data Pasien yang tidak Preeklampsia

\begin{tabular}{|c|c|c|c|c|}
\hline \multirow{2}{*}{$\begin{array}{l}\text { Klasifikasi } \\
\text { Usia Ibu }\end{array}$} & \multicolumn{2}{|c|}{ Tidak Preeklampsia } & \multirow[b]{2}{*}{ Total } & \multirow[b]{2}{*}{$\%$} \\
\hline & $\begin{array}{l}\text { Primi- } \\
\text { gravida }\end{array}$ & $\begin{array}{l}\text { Multi- } \\
\text { gravida }\end{array}$ & & \\
\hline$<20$ tahun & 1 & 0 & 1 & 1,2 \\
\hline 20-35 tahun & 22 & 52 & 74 & 91,4 \\
\hline$>35$ tahun & 2 & 4 & 6 & 7,4 \\
\hline Total & 25 & 56 & 81 & \\
\hline$\%$ & 30,9 & 69,1 & & 100 \\
\hline
\end{tabular}

Dari tabel 2 dapat dilihat bahwa frekuensi multigravida $(69,1 \%)$ yang tidak menderita preeklampsia lebih banyak daripada frekuensi primigravida $(30,9 \%)$. Hampir seluruh pasien yang tidak mederita preeklampsia berusia 20 - 35 tahun $(91,4 \%)$.

\section{Hubungan Status Gravida dengan Kejadian Preeklampsia}

Tabel 3. Hubungan Status Gravida dengan Preeklampsia

\begin{tabular}{cccccc}
\hline \multirow{2}{*}{ Status Gravida } & \multicolumn{2}{c}{ Preeklampsia } & \multirow{2}{*}{ Total } & $X^{2}$ & nilai \\
\cline { 2 - 3 } & Ya & Tidak & & & $\mathrm{p}$ \\
\hline Primigravida & 38 & 25 & 63 & 4,39 & 0,036 \\
Multigravida & 43 & 56 & 99 & & \\
\hline Total & 81 & 81 & 162 & & \\
\hline
\end{tabular}

Pada tabel 3 dapat dilihat bahwa dari 63 ibu primigravida, 38 orang (46,9\%) menderita preeklampsia dan sebanyak 25 orang (30,9\%) tidak menderita preeklampsia. Proporsi primigravida yang menderita preeklampsia 1,52 kali lebih banyak daripada primigravida yang tidak menderita preeklampsia. Pada tabel 3 terlihat 56 orang (69,1\%) multigravida tidak menderita preeklampsia dan yang menderita preeklampsia ada 43 orang (53,1\%). Proporsi multigravida yang tidak menderita preeklampsia 1,3 kali lebih banyak daripada multigravida yang menderita preeklampsia.

Hasil uji statistik dengan chi square didapatkan nilai $X^{2}=4,39$ dan nilai $p=0,036(p<$ $0,05)$, artinya terdapat hubungan yang signifikan antara status gravida ibu dengan kejadian preeklampsia di RSUP Dr. M. Djamil Padang pada tahun 2012 - 2013. Hal ini menunjukkan bahwa primigravida mempunyai kecenderungan untuk mengalami preeklampsia dibandingkan dengan multigravida.

\section{Hubungan Usia Ibu dengan Kejadian Preeklampsia}

Tabel 4. Hubungan usia ibu dengan preeklampsia

\begin{tabular}{|c|c|c|c|c|c|}
\hline \multirow{2}{*}{ Usia Ibu } & \multicolumn{2}{|c|}{ Preeklampsia } & \multirow{2}{*}{ Total } & \multirow{2}{*}{$x^{2}$} & \multirow{2}{*}{$\begin{array}{c}\text { Nilai } \\
\mathrm{p}\end{array}$} \\
\hline & $\mathrm{Ya}$ & Tidak & & & \\
\hline $\begin{array}{c}\text { Risiko Tinggi } \\
\text { (<20 tahun dan } \\
>35 \text { tahun) }\end{array}$ & 31 & 7 & 38 & $\begin{array}{c}19,8 \\
03\end{array}$ & $\begin{array}{c}0,00 \\
1\end{array}$ \\
\hline $\begin{array}{l}\text { Risiko Rendah } \\
\text { (20 - } 35 \text { tahun) }\end{array}$ & 50 & 74 & 124 & & \\
\hline & 81 & 81 & 162 & & \\
\hline
\end{tabular}

Pada tabel 4 dapat dilihat bahwa dari 38 orang ibu yang berusia dalam kategori usia risiko tinggi ( $<20$ tahun dan $>35$ tahun), 31 orang (38,3\%) menderita preeklampsia dan 7 orang $(8,6 \%)$ tidak menderita preeklampsia. Proporsi ibu yang berusia dalam kategori usia risiko tinggi dan menderita preeklampsia 4,43 kali lebih banyak daripada yang tidak menderita preeklampsia. Pada tabel terlihat 74 orang $(91,4 \%)$ yang berusia dalam kategori usia risiko rendah atau usia reproduktif (20 - 35 tahun) tidak menderita preeklampsia dan ada 50 orang $(61,7 \%)$ yang menderita preeklampsia. Proporsi ibu yang berusia dalam kategori usia risiko rendah yang tidak menderita preeklampsia 1,48 kali lebih banyak daripada yang menderita preeklampsia

Hasil uji statistik dengan chi square didapatkan nilai $X^{2}=19,803$ dan nilai $p=0,001(p<$ $0,05)$, artinya terdapat hubungan yang signifikan antara usia ibu dengan kejadian preeklampsia di RSUP Dr. M. Djamil Padang pada tahun 2012 - 2013. Hal ini menunjukkan bahwa ibu yang berusia $<20$ 
tahun dan > 35 tahun mempunyai kecenderungan untuk mengalami preeklampsia dibandingkan dengan ibu yang berusia $20-35$ tahun.

\section{PEMBAHASAN}

Preeklampsia adalah penyakit dengan gejala klinis berupa hipertensi dan proteinuria yang timbul karena kehamilan akibat vasospasme dan aktivasi endotel saat usia kehamilan di atas 20 minggu. $^{1,2}$ Preeklampsia merupakan salah satu penyulit dalam kehamilan yang menyebabkan sakit berat, kecacatan jangka panjang, serta kematian pada ibu, janin dan neonatus. $^{4,5}$

Pada penelitian ini ditemukan proporsi primigravida yang menderita preeklampsia 1,52 kali lebih banyak daripada primigravida yang tidak preeklampsia, sedangkan proporsi multigravida yang tidak menderita preeklampsia 1,3 kali lebih banyak daripada multigravida yang menderita preeklampsia. Berdasarkan analisis statistik menggunakan uji chi square, ditemukan adanya hubungan yang signifikan antara status gravida dengan kejadian preeklampsia. Maknanya, seorang primigravida mempunyai kecenderungan untuk mengalami preeklampsia dibandingkan dengan multigravida. Hasil ini sesuai dengan penelitian yang dilakukan di Rumah Sakit Dr.

$H$. Soewondo Kendal yang menunjukkan hubungan yang signifikan antara status gravida dengan preeklampsia. Pada penelitian case control tersebut disimpulkan bahwa primigravida mempunyai faktor risiko menderita preeklampsia 2,2 kali lebih besar dibandingkan multigravida. Pada RSUD Dr. Moewardi Surakarta ditemukan 35 dari 60 primigravida menderita preeklampsia dan hanya 24 dari 60 multigravida yang menderita preeklampsia. Dari hasil uji chi square nilai $\mathrm{p}=0,045$ yang berarti bahwa terdapat hubungan yang signifikan antara primigravida dengan kejadian preeklampsia dimana pada primigravida berisiko 1,458 kali lebih besar untuk menderita preeklampsia dibandingkan multigravida. ${ }^{10}$ Penelitian yang dilakukan di RSU Bhakti Yudha Depok juga mendapatkan bahwa primigravida merupakan faktor risiko terjadinya preeklampsia. ${ }^{8,10,11}$

Secara teori, primigravida lebih berisiko untuk mengalami preeklampsia daripada multigravida karena preeklampsia biasanya timbul pada wanita yang pertama kali terpapar vilus korion. Hal ini terjadi karena pada wanita tersebut mekanisme imunologik pembentukan blocking antibody yang dilakukan oleh HLA-G (human leukocyte antigen G) terhadap antigen plasenta belum terbentuk secara sempurna, sehingga proses implantasi trofoblas ke jaringan desidual ibu menjadi terganggu. Primigravida juga rentan mengalami stres dalam menghadapi persalinan yang akan menstimulasi tubuh untuk mengeluarkan kortisol. Efek kortisol adalah meningkatkan respon simpatis, sehingga curah jantung dan tekanan darah juga akan meningkat. ${ }^{1,12,13}$

Penelitian ini menemukan proporsi ibu yang berusia dalam kategori usia risiko tinggi $(<20$ tahun dan > 35 tahun) dan menderita preeklampsia 4,43 kali lebih banyak daripada yang tidak menderita preeklampsia, sedangkan proporsi ibu yang berusia dalam ketegori usia risiko rendah (20 - 35 tahun) dan tidak menderita preeklampsia 1,48 kali lebih banyak daripada yang menderita preeklampsia. Berdasarkan analisis statistik menggunakan uji chi square, ditemukan adanya hubungan yang signifikan antara usia ibu dengan kejadian preeklampsia. Maknanya, ibu yang berusia $<20$ tahun dan $>35$ tahun mempunyai kecenderungan untuk mengalami preeklampsia dibandingkan dengan ibu yang berusia 20 - 35 tahun. Penelitian sebelumnya juga mendapatkan bahwa terdapat hubungan $(p=0,00)$ antara ibu yang memiliki usia pada kategori risiko tinggi dengan kejadian preeklampsia dan nilai OR sebesar 3,73 . Pada penelitian lain juga didapatkan bahwa ibu yang berusia dalam kategori usia risiko tinggi memiliki risiko 5,089 kali mengalami preeklampsia dibandingkan dengan ibu yang berusia dalam kategori usia risiko rendah. ${ }^{14,15}$

Usia reproduktif dari seorang wanita adalah 20 - 35 tahun. Usia reproduktif ini merupakan periode yang paling aman untuk hamil dan melahirkan karena pada usia tersebut risiko terjadinya komplikasi selama kehamilan lebih rendah. Usia di bawah 20 tahun dan di atas 35 tahun disebut juga sebagai usia risiko tinggi untuk mengalami komplikasi selama kehamilan. Pada usia $<20$ tahun, ukuran uterus belum mencapai ukuran yang normal untuk kehamilan, sehingga kemungkinan terjadinya gangguan dalam kehamilan seperti preeklampsia menjadi lebih besar. Pada usia > 35 
tahun terjadi proses degeneratif yang mengakibatkan perubahan sruktural dan fungsional yang terjadi pada pembuluh darah perifer yang bertanggung jawab terhadap perubahan tekanan darah, sehingga lebih rentan mengalami preeklampsia. ${ }^{1,4,16,17}$

Penelitian yang dilakukan oleh Rozikhan (2007) didapatkan hubungan antara usia< 20 tahun dengan kejadian preeklampsia, namun tidak terdapat hubungan antara usia > 35 tahun dengan kejadian preeklampsia. Berbanding terbalik dengan Rozikhan, penelitian yang dilakukan El- Gilany (2012) menemukan bahwa tidak ada hubungan antara usia ibu $<20$ tahun dengan preeklampsia, namun terdapat hubungan yang signifikan antara usia ibu > 35 tahun dengan kejadian preeklampsia.,

Pada penelitian ini analisis usia ibu tidak dapat dilakukan dengan kategori usia $<20$ tahun, $20-$ 25 tahun dan > 35 tahun karena pada saat pengolahan data terdapat $33,3 \%$ sel dengan expected count yang kurang dari 5, sehingga usia $<20$ tahun dan > 35 tahun digabungkan menjadi kategori usia tinggi. Hal ini mungkin disebabkan karena jumlah sampel pada penelitian ini yang kurang sehingga sampel penelitiannya tidak mewakili seluruh populasi.

\section{KESIMPULAN}

Terdapat hubungan yang bermakna antara status gravida dengan kejadian preeklampsia, dimana primigravida mempunyai kecenderungan untuk menderita preeklampsia daripada multigravida.

Terdapat hubungan yang bermakna antara usia ibu dengan kejadian preeklampsia, dimana ibu hamil yang berusia dalam kategori usia risiko tinggi mempunyai kecenderungan untuk menderita preeklampsia daripada ibu yang berusia dalam kategori usia risiko rendah.

\section{DAFTAR PUSTAKA}

1. Cunningham FG, Leveno KJ, Hauth JC, Bloom SL, Rouse DJ, Spong CY. Williams obstetric

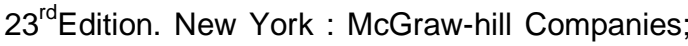
2010.

2. Eiland E, Nzerue C, Faulkner M. Review article : preeklampsia 2012. Journal of Pregnancy. 2012; Volume 2012 (586578):1-7.
3. Sofoewan S. Preeklampsia-eklampsia di beberapa rumah sakit di Indonesia, Patogenesis dan kemungkinan pencegahannya. Pidato Pengukuhan Jabatan Guru Besar pada Fakultas Kedokteran Universitas Gadjah Mada. Yogyakarta: Rapat Terbuka Majelis Guru Besar Universitas Gadjah Mada; 2003.

4. Bastani P, Kobra H, Hossein N. Risk factors for preeclampsia in multigravida woman. Research Journal of Biological Sciences. 2008;3(1):148-53.

5. (World Health Organization) WHO. Recommendations for prevention and treatment of pre-eclampsia and eclampsia, summary of recommendations. Switzerland: Department of Reproductive Health and Research World Health Organization; 2011.

6. Serrano NC. Immunologi and genetic of preeclampsia. Clinical \& Developmental Immunology. 2006;13(2-4):197.

7. Chappell LC, Enye S, Seed P, Briley AL, Poston $\mathrm{L}$, Shennan $\mathrm{AH}$. adverse perinatal outcomes and risk factors for preeclampsia in women with chronic hypertension. Hypertension. 2008;2008(51):1002-9.

8. Rozikhan. Faktor-faktor risiko terjadinya preeklampsia berat di rumah sakit Dr. H. Soewondo Kedal (tesis). Semarang: Universitas Diponegoro; 2007. .

9. Lee CT, Williams GH, Lilly LS. Hypertension. In ( Lilly $S$ ed) Pathophysiology of heart disease, $5^{\text {th }}$ ed. Philadelphia : LippincottWilliams \& Wilkins; 2011. pp 301-23.

10. Artikasari K. Hubungan antara primigravida dengan angka kejadian preeklamsia/eklamsia di RSUD dr. Moewardi Surakarta Periode 1 Januari - 31 Desember 2008 (skripsi); 2009.

11. Nofiansyah R. Hubungan antara primigravida dengan preeklampsia/eklampsia di RSU Bhakti Yudha Depok Periode Januari 2006 - Desember 2010 (skripsi); 2011.

12. Yie SM, Li LH, Xiao R, Librach CL. A single basepair mutation in the 3 '-untranslated region of HLA-G mRNA is associated with pre-eclampsia. Molecular Human Reproduction. 2008; 14(11): 649-53. 
13. Moffatt, FW. A randomized controlled trial of the efects of guided imagery on blood pressure in hypertensive pregnant women (tesis). Canada: University of Toronto; 2008.pp 9-59.

14. Langelo $W$, Arsin $A A$, Russeng $S$. Faktor risiko kejadian preeklampsia di Rskd lbu dan Anak Siti Fatimah Makassar Tahun 2011-2012 (tesis). Makassar: Universitas Hasanuddin; 2012.

15. Gafur A, Nurdin A, Ramadhany S, Rahim MR. Hubungan antara primigravida dengan preeklampsia. Jurnal Online Fakultas Kedokteran Universitas Muhammadiyah Makassar. 2011 (diunduh 14 Januari 2014). Tersedia dari: URL:
HYPERLINK http://www.jurnal.med.unismuh. ac.id/hubungan-antara-primigravida-denganpreeklampsia/

16. Strom JB, Libby P. Hypertension. In ( Lilly S ed) Pathophysiology of Heart Disease, ${ }^{5 \text { th }}$ ed. Philadelphia : LippincottWilliams \& Wilkins; 2011. pp 127-33.

17. El-Gilany $\mathrm{AH}$, Hammad S. Obstetric outcomes of teenagers and older mothers: experience from Saudi Arabia. International Journal of Collaborative Research on Internal Medicine \& Public Health. 2012 4(6): 903. 